\title{
Phosphorus Availability for Irrigated Rice Cultivated Under No-Tillage and Different Phosphate Sources
}

\author{
Magali de Ávila Fortes ${ }^{1}$, Rogério Oliveira de Sousa ${ }^{2}$, Algenor da Silva Gomes ${ }^{3}$, Fabiana Schmidt ${ }^{4}$, \\ Walkyria Bueno Scivittaro ${ }^{3}$, Luis Henrique Gularte Ferreira ${ }^{5}$, Juliana Brito da Silva Teixeira ${ }^{2}$ \\ \& Thaís Antonili Veçozzi ${ }^{2}$ \\ ${ }^{1}$ Rural Extension and Technical Assistance Institute, Brazlândia, DF, Brazil \\ ${ }^{2}$ Program on Soil and Water Management and Conservation, Federal University of Pelotas, Capão do Leão, RS, \\ Brazil \\ ${ }^{3}$ Embrapa Clima Temperado, Pelotas, RS, Brazil \\ ${ }^{4}$ Agricultural Research and Rural Extension of Santa Catarina, Itajaí, SC, Brazil \\ ${ }^{5}$ Institute of Education, Science and Technolog, Rio Grande, RS, Brazil \\ Correspondence: Juliana Brito da Silva Teixeira, Program on Soil and Water Management and Conservation, \\ Federal University of Pelotas, Av. Eliseu Maciel, CEP: 96050-500, Capão do Leão, RS, Brazil. Tel: \\ 55-53-999-295-049. E-mail: julianabrit@gmail.com
}

Received: January 16, 2018

doi:10.5539/jas.v10n5p276
Accepted: March 2, $2018 \quad$ Online Published: April 15, 2018

URL: https://doi.org/10.5539/jas.v10n5p276

\begin{abstract}
The objective of this work was to evaluate the response of irrigated rice to phosphate fertilization using triple superphosphate (TSP) and Arad phosphate rock (APR), and the phosphate residual effects of upland crops in no-tillage system on the following rice crop. Also, it aimed to evaluate the efficiency of Mehlich-1 and anion exchange resin as soil P extractors. Two experiments were conducted in Albaqualf soil under irrigated conditions in the southern region of Rio Grande do Sul State. The experiments were designed as random blocks with four replications and the treatments were displayed as a $2 \times 2$ factorial (TSP and APR, with and without annual P application as TSP). No yield responses to phosphate were observed. Phosphate fertilization performed on upland crops (maize and soybeans) presented a residual effect on the rice crop even after four years of consecutive cropping under no-tillage. The extractors Mehlich-1 and AER were equally efficient in the evaluation of $\mathrm{P}$ availability for the rice crop. $\mathrm{P}$ content values obtained by both methods did show a significant correlation with accumulated plant P. The APR presents a similar performance as the TSP in regard to phosphate nutrition in irrigated rice when rotated with upland crops under no-tillage system.
\end{abstract}

Keywords: lowland, phosphate rock, triple superphosphate

\section{Introduction}

Soluble phosphate fertilizers are readily dissolved in the soil releasing high $\mathrm{P}$ concentrations, leading to higher $\mathrm{P}$ uptake and fast growth of plants. However, these phosphate sources loose their efficiency over time since P adsorption occurs converting it to non-labile forms. Natural reactive phosphates slowly get into solution and normally are more efficient to be used at medium term.

Combinations of soluble and rock phosphate can consist in a good strategy for the supply of $\mathrm{P}$ to the irrigated rice cultivated as a single crop or in crop rotations (Ferreira et al., 2007). Some reports have shown a positive effect on rice grain yield after four years of phosphate rock (PR) fertilizer use, indicating a residual effect of $\mathrm{P}$ for the following crop (Gomes et al., 2005).

The one-year residual effect is higher after two successive applications in comparison to only one application, after two years or more for both situations (Nakamura et al., 2016). It is possible that the residual effect remains for longer, but it was not possible to detect in this experiment.

The introduction of irrigated rice in no-tillage crop rotation systems can promote changes in the P availability in the soil. During soil flooding, iron oxides are considered as P sources for the rice plants, since anaerobic bacteria 
use ferric oxide as electron receptors in the respiration process, reducing them to ferrous oxides. The latter are more soluble, promoting P desorption (Sousa et al., 2009). In such an environment, P uptake by plants can occur.

Many P extraction methods have produced good results regarding the phosphate fertilizer used for the upland crop (Chang, 1978). However, in flooded soils, P levels increase significantly due to soil reduction, but varying according to soil type. Since most methods include the analysis of dry soil samples, they miss possible changes in $\mathrm{P}$ availability after flooding, not reflecting a true condition of $\mathrm{P}$ availability to rice in flooded soils. The Mehlich-1 extractor $\left(\mathrm{H}_{2} \mathrm{SO}_{4} 0.025 \mathrm{~N}+\mathrm{HCl} 0.05 \mathrm{~N}\right)$ is the most commonly used method in Brazil. This method is based on maintaining $\mathrm{H}^{+}$activity in the solution. This activity is sufficient for the partial dissolution of calcium phosphate and $\mathrm{Fe}$ and $\mathrm{Al}$ oxides (Lindsay, 1979). Although presenting only a fair predictive value for the $\mathrm{P}$ availability in State soils cultivated with rice, no other method has provided significantly better results in order to justify its replacement (Silva et al., 2008).

The method of $P$ extraction based on ion exchange resins was initially proposed by Amer et al. (1955). In Brazil, only the State of São Paulo uses this method in routine labs. Ion exchange resins are synthetic products that present a tridimensional hydrocarbon chain net containing functionally charged groups $\left(-\mathrm{NR}_{3}+\mathrm{OH}^{-}\right)$that simulate a strong alkali compound which dissociates in any $\mathrm{pH}$ value (Silva \& Raij, 1999). In the P extraction process, the element is transferred to the resin, causing its adsorption (Raij et al., 1986).

An advantage of this method as opposed to Mehlich-1 is that the extraction is persistent and it uses water in a similar manner to $\mathrm{P}$ uptake by plant roots and does not use any energetic chemical reagents which could dissolve non-labile phosphates. According to the Committee of Soil Chemistry and Fertility-RS/SC (2004), this method is indicated for the diagnoses of $\mathrm{P}$ availability in soils that were fertilized with phosphate rocks over two years. The interpretation is though performed independent from Clay or soil flooding levels.

The objectives of this work were to evaluate the response of irrigated rice to phosphate fertilizer using triple superphosphate (TSP) and Arad phosphate rock (APR). Also, to evaluate the residual effect of P applied on upland crops under no-tillage system to the following rice crop and the efficiencies of Mehlich-1 and anion exchange resin methods as soil $P$ extractors.

\section{Material and Methods}

In order to achieve the proposed objectives, two experiments were performed in the southern region of Rio Grande do Sul State. One experiment was conducted for a period of 5 years in a Typic Albaqualf soil (Soil Survey Staff, 2010) in the Field belonging to the Lowland Station of Embrapa Temperate Climate. The experiments were designed as random blocks with four replications in a $2 \times 2$ factorial (Triple SuperphosphateTSP and Arad Phosphate Rock-APR, with and without annual application of P as TSP). Also, a control treatment was included without any phosphate fertilizer application. One experiment was conducted with soybean and ryegrass on the summer and winter, respectively. The other experiment had maize in the summer and ryegrass + white clover in the winter. The area covered by each plot was $20 \mathrm{~m}^{2}$.

The upland crops were cultivated in the same area for four years under no-tillage cropping. Winter crops were desiccated with a total action herbicide and the plant residues remained on the soil surface. During the summer of the fifth year, all plots were sown with rice cultivar Atalanta under no-tillage on the desiccated residue of upland crops.

$\mathrm{P}$ doses were established as a function of an initial soil analysis performed before setting the experiments: water pH: 5.5 (soil/water ratio of 1:1); O.M.: 2.2\% (Walkley-Black wet oxidation method); K: $39.9 \mathrm{mg} \mathrm{dm}^{-3}$, Na: 48 mg dm${ }^{-3}$ and P: $1.5 \mathrm{mg} \mathrm{dm}^{-3}$ (Mehlich-1); Al: $0.6 \mathrm{cmol}_{\mathrm{c}} \mathrm{dm}^{-3}$, Ca: $2.2 \mathrm{cmol}_{\mathrm{c}} \mathrm{dm}^{-3}$ and $\mathrm{Mg}: 1.3 \mathrm{cmol}_{\mathrm{c}} \mathrm{dm}^{-3}$ (1 mol $\mathrm{L}^{-1} \mathrm{KCl}$ ); and clay content: $20 \%$.

Phosphate fertilizers were in the order of $110 \mathrm{~kg} \mathrm{ha}^{-1}$ for maize and $120 \mathrm{~kg} \mathrm{ha}^{-1}$ for soybean. $\mathrm{K}$ and $\mathrm{N}$ fertilizers were also applied for maize $\left(100 \mathrm{~kg} \mathrm{ha}^{-1} \mathrm{KCl}\right.$ and $130 \mathrm{~kg} \mathrm{ha}^{-1} \mathrm{~N}$ as urea, respectively) and $\mathrm{K}$ for soybean $(90 \mathrm{~kg}$ $\left.\mathrm{ha}^{-1} \mathrm{KCl}\right)$.

Before the rice crop, at the fifth year of experiments, soil samples were collected at two depths $(0-10 \mathrm{~cm}$ and 0-20 cm). Soil samples were dried and sieved ( $2 \mathrm{~mm}$ sieve). In the soil, P content was assessed by Mehlich-1 and AER on $5.0 \times 2.0 \mathrm{~cm}$ layers. Plant tissues were analyzed for P content $\left(\mathrm{g} \mathrm{kg}^{-1}\right)$ according to the method described by Tedesco et al. (1995). A total of 50 flag leaves were collected per plot at full flowering stage. At the end of the crop cycle, a $0.50 \mathrm{~m}$ linear sample of plants was collected per plot and dried at $65^{\circ} \mathrm{C}$ for 72 hours. After, $\mathrm{P}$ and shoot (culms, leaves and grains) dry matter contents were measured. Grain harvest for yield assessment were performed after physiological maturation in an area of $8.40 \mathrm{~m}^{2}$ per plot. 
Statistical analyses were performed by partitioning the variation among treatments (ANOVA) considering a 2 x 2 factorial, the additional treatment, as well as the design (random blocks with four replications). Factors consisted as follows: Factor $\mathrm{A}-\mathrm{P}_{2} \mathrm{O}_{5}$ source (A1: TSP and A2: APR) and factor $\mathrm{B}$ - phosphate fertilizer application (B1: without $\mathrm{P}_{2} \mathrm{O}_{5}$ reapplication and $\mathrm{B} 2$ : with $\mathrm{P}_{2} \mathrm{O}_{5}$ reapplication). The additional treatment consisted of a control without $\mathrm{P}$ application.

In the general conditions used, the model can be expressed by the following equation:

$$
Y i j=m+t i+b j+E E i j
$$

Where,

Yij: response observed on the plot that received the $i_{-t h}$ treatment on the $j_{-t h}$ block; $m$ : experiment mean value; $t i$ : effect of the $i_{-t h}$ treatment; $b j$ : effect of $j_{-t h}$ block; EEij: experimental error that received the $i_{-t h}$ treatment at the $j^{-}{ }_{t h}$ block.

For the partitioning of treatment effects that form the factorial structure, the procedures described by Zimmermann (2004) were used: use of orthogonal contrasts in order to isolate the factorial effects and partitioning of factorial into principal effects and their interactions. According to Zimmermann (2004), when the experimental factors show only two levels, there is no need to perform a test complementary to $F$ for the comparison of means. For correlation analyses, the Winstat software was used (Machado, 2001).

\section{Results and Discussion}

The Phosphate fertilization increased $\mathrm{P}$ contents in the soil as detected by both extraction methods. These contents were different from the control without fertilizer application (Table 1). P contents extracted by Mehlich-1 were inferior to the critical levels of $6.0 \mathrm{mg} \mathrm{dm}^{-3}$ in the maize desiccated residue area for flooded soils (Committee of Soil Chemistry and Fertility-RS/SC, 2004). In the soybean desiccated residue area, P contents were higher than $6.0 \mathrm{mg} \mathrm{kg}^{-1}$ at both depths $(0-10 \mathrm{~cm}$ and $0-20 \mathrm{~cm})$ when there was reapplication of phosphate fertilizer.

Table 1. Soil extracted P contents using Mehlich-1 and anion Exchange resin (AER) from two depths of a Typic Albaqualf after harvesting of maize and soybean with and without phosphate application (w/r and wo/r)

\begin{tabular}{|c|c|c|c|c|c|c|c|c|c|c|c|c|}
\hline \multirow{3}{*}{ Phosphate Fertilizers } & & \multicolumn{11}{|c|}{ Depths } \\
\hline & & \multicolumn{2}{|c|}{$0-10 \mathrm{~cm}$} & & \multicolumn{2}{|c|}{$0-20 \mathrm{~cm}$} & & \multicolumn{2}{|c|}{$0-10 \mathrm{~cm}$} & & \multicolumn{2}{|c|}{$0-20 \mathrm{~cm}$} \\
\hline & & wo/r & $\mathrm{w} / \mathrm{r}$ & & wo $/ \mathrm{r}$ & $\mathrm{w} / \mathrm{r}$ & & wo/r & $\mathrm{w} / \mathrm{r}$ & & wo/r & $\mathrm{w} / \mathrm{r}$ \\
\hline & 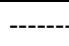 & -ב---- & M & ze ---- & - n & -------- & - ----- & -ב----- & --- Soy & bean -- & -1----- & - \\
\hline Without $\mathrm{P}_{2} \mathrm{O}_{5}$ & $3.9^{*}$ & & & 2.7 & & ent & $3.3^{*}$ & & & $2.8^{*}$ & & -- \\
\hline TSP & & $4.2 \mathrm{Ab}$ & $5.4 \mathrm{Aa}$ & & $3.1 \mathrm{Ab}$ & $4.2 \mathrm{Aa}$ & & $4.0 \mathrm{Ab}$ & $11.3 \mathrm{Aa}$ & & $3.6 \mathrm{Ab}$ & $10.2 \mathrm{Aa}$ \\
\hline APR & & $5.2 \mathrm{Aa}$ & $5.8 \mathrm{Aa}$ & & $3.6 \mathrm{Ab}$ & 4.3Aa & & $4.0 \mathrm{Ab}$ & $9.8 \mathrm{Aa}$ & & $4.7 \mathrm{Ab}$ & 7.9Aa \\
\hline \multirow[t]{2}{*}{ CV \% } & 15.1 & & & 9.8 & & & 20.0 & & & 18.0 & & \\
\hline & ----- & ------- & -1------ & $-\cdots$ & ------- & $--\mathrm{AEF}$ & $\left.g^{-1}\right)-$ & -------- & 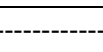 & ----- & -1------ & ------- \\
\hline Without $\mathrm{P}_{2} \mathrm{O}_{5}$ & $6.1^{*}$ & & & $5.4^{*}$ & & & $5.9^{*}$ & & & $8.6^{*}$ & & \\
\hline TSP & & $7.7 \mathrm{Bb}$ & $34.5 \mathrm{Aa}$ & & $8.5 \mathrm{Ab}$ & $23.1 \mathrm{Aa}$ & & $7.8 \mathrm{Bb}$ & $28.2 \mathrm{Ba}$ & & $10.0 \mathrm{Ab}$ & $21.5 \mathrm{Ba}$ \\
\hline APR & & $9.2 \mathrm{Ab}$ & $47.8 \mathrm{Aa}$ & & $8.5 \mathrm{Ab}$ & $27.6 \mathrm{Aa}$ & & $9.9 \mathrm{Ab}$ & $47.0 \mathrm{Aa}$ & & $10.8 \mathrm{Ab}$ & $30.3 \mathrm{Aa}$ \\
\hline $\mathrm{CV} \%$ & 20.7 & & & 18.9 & & & 24.8 & & & 18.3 & & \\
\hline
\end{tabular}

Note. * Control differs from remaining treatments. Means followed by distinct capital letters on the column and low capital letters on the row differ statistically with the $\mathrm{F}$ test $(<5 \%)$. Control: without $\mathrm{P}_{2} \mathrm{O}_{5}$ application, TSP: recommended dose of $\mathrm{P}_{2} \mathrm{O}_{5}$ as TSP with and without annual reapplication; APR: recommended dose of $\mathrm{P}_{2} \mathrm{O}_{5}$ as PR from Arad with and without annual reapplication with TSP.

There were no differences between P sources regardless the depth and area analyzed, but the annual reapplication of the recommended dose lead to increases in soil P contents (Table 1). The extracted P contents obtained by AER were higher than the critical level only in those treatments with annual fertilizer reapplication for both areas analyzed. The critical level suggested by the Committee of Soil Chemistry and Fertility-RS/SC (2004) is $20 \mathrm{mg}$ $\mathrm{dm}^{-3}$ (Table 1). As opposed to the results from the Mehlich-1 extractor, there were differences in P contents extracted by the AER between the two sources, where the APR lead to higher P contents in the maize desiccated 
residue area without the reapplication of fertilizer at $0-10 \mathrm{~cm}$ depth, and in the soybean desiccated residue at depth of $0-10 \mathrm{~cm}$ with and without fertilizer reapplication and at $0-20 \mathrm{~cm}$ only with fertilizer reapplication.

The P contents extracted by AER were higher than those obtained by Mehlich-1. Studies show that the ion exchange resin extracts more phosphorus than the Mehlich-1 (Freitas et al., 2013; Gatiboni, 2003). The higher P amounts extracted are due to the use of $\mathrm{NaHCO}_{3}$ by the resin method to perform the ionic exchange with phosphorus. Also, the time spent with agitating the soil solution is higher $(16 \mathrm{~h})$ than for Mehlich-1 (5 min) (Bortolon, 2005). This feature of AER makes it more efficient to predict $\mathrm{P}$ availability in soils fertilized with Natural Phosphate (Oliveira et al., 2015). According to Simonete et al. (2015), in soils cultivated with rice under flooding systems, the methods EDTA and Mehlich-3 were the most satisfactory in the prediction of P availability. However, when the soils were Split in two groups according to their P adsorption ability, the methods Melich-1 and AER were also eficiente in evaluating the P availability. The strategy of soil division in buffering classes is advised by Rogeri et al. (2017), who demonstrated an improvement in the predictive ability of Melich-1 and Melich-3 methods when such strategy was used.

A correlation between soil P contents extracted from the different methods, regardless of source, depth and area was detected (Figure 1). The highest correlation coefficients $(r=0.79$ and $r=0.84)$ obtained between the two methods were observed at 0-20 cm depth (Figure 1b, Figure 1d), probably due to the dilution effect of APR at this depth. A common procedure for no-tillage systems in low $\mathrm{P}$ availability soils is to apply and incorporate soluble phosphate fertilizers and preferably reactive phosphate rocks before the first crop, homogenizing the phosphate in the arable layer at $0-20 \mathrm{~cm}$ (Anghinoni, 2006). In this experiment, the phosphate fertilizer was incorporated at the early steps of no-tillage and could explain the obtained results.

a)

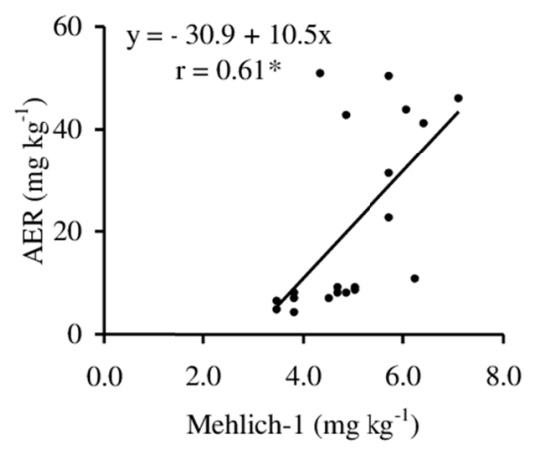

c)

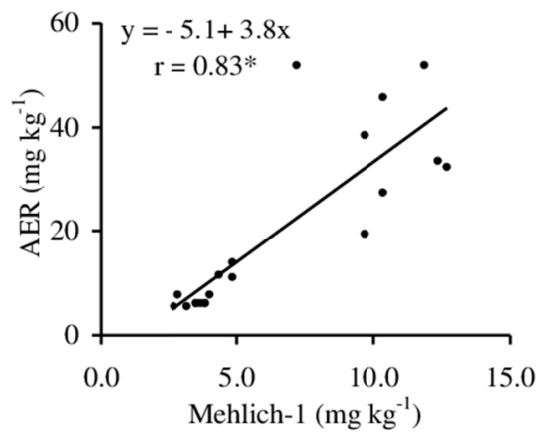

b)

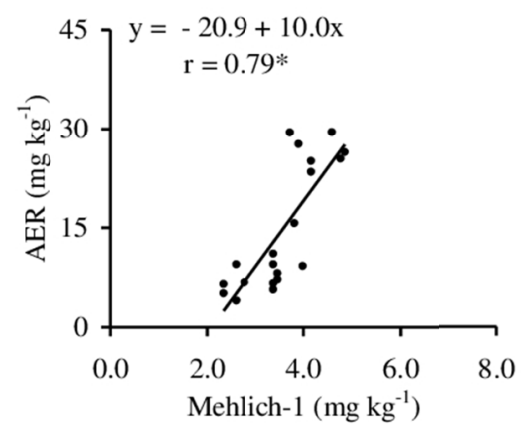

d)

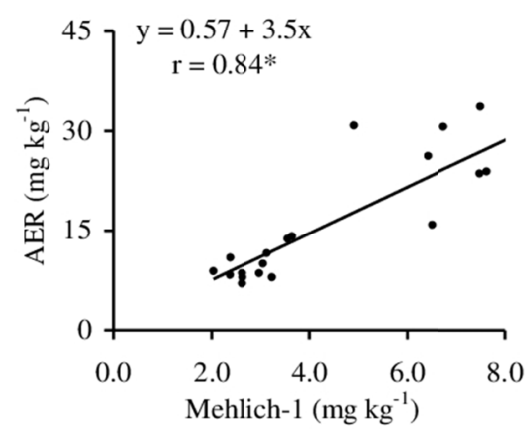

Figure 1. Correlations between extracted P values considering the Mehlich-1 and anion exchange resin (AER) methods for areas after no-tillage cultivation with maize at $0-10 \mathrm{~cm}$ (a) and $0-20 \mathrm{~cm}(\mathrm{~b})$, and soybean at $0-10 \mathrm{~cm}$ (c) and $0-20 \mathrm{~cm}(\mathrm{~d})$ depths. ${ }^{*}$ Significant at $<1 \%$ probability

Many authors (Kurihara et al., 2016; Freitas et al., 2013; Steiner et al., 2012; Gonçalves \& Meurer, 2008) have observed a good correlation between both methods, but correlation coefficients ranged from soil to soil, since both the soil type and fertilizer source influence the efficiency of $\mathrm{P}$ extraction by both methods. According to the Committee of Soil Chemistry and Fertility-RS/SC (2004), AER soil P analysis is indicated for the diagnosis of 
soil P availability in soils fertilized with phosphate rock after two years. On the other hand, since Mehlich-1 is an acid extraction method, it could dissolve non-labile phosphates. However, due to the simplicity and speed of this method, Mehlich-1 is the most used in Brazil, and is based on maintaining enough $\mathrm{H}^{+}$activity in the solution for the partial dissolution of calcium phosphates and Fe and Al oxides (Lindsay, 1979). The P extraction method using the AER is based on desorption or dissolution of $\mathrm{P}$ from the soil solid phase for reestablishing the equilibrium with the P dissolved in the soil suspension (Silva \& Raij, 1996). The reading of P contents extracted by the resin is performed independently from Clay content or soil flooding (Committee of Soil Chemistry and Fertility-RS/SC, 2004).

According to Skogley and Dobermann (1996) in the AER method, the P extracted is linked to the colloid surface, until the electrochemical equilibrium between the soil-solution-resin is obtained. The Mehlich-1 method can cause the solution of soil stable $\mathrm{P}$ compounds in the soil that do not contribute to $\mathrm{P}$ in solution, especially calcium phosphates (Raij et al., 1986; Oliveira et al., 2015) Nevertheless, the present study did not present higher P contents when the Mehlich-1 was compared to the AER method (Table 1).

A report from Cardoso (2007) disagrees with Silva and Raij (1996), which state that one of the advantages of the AER method is to avoid the overestimation of $\mathrm{P}$ availability as much as the acid extractors in soils fertilized with phosphate rocks. This author observed lower correlation coefficients between the $\mathrm{P}$ accumulated in the rice plants and the $\mathrm{P}$ extracted by the resin in a soil fertilized with phosphate rock $(\mathrm{r}=0.47)$ when compared to the triple superphosphate $(\mathrm{r}=0.67)$.

The phosphate fertilizer, independently from reapplication and $\mathrm{P}$ sources increased $\mathrm{P}$ content in the rice plants (Table 2). The higher $\mathrm{P}$ contents in flag leaves and rice shoots were observed when there was an annual reapplication of phosphate fertilizer. Differences between phosphate sources in the soybean desiccated residue and were only observed on shoot P contents, always showing lower values for APR when compared to TSP.

Table 2. P contents in rice flag leaf and shoot (culms, leaves and grains) from no-tillage areas after maize and soybean cultivation, with and without reapplication of phosphate fertilizer $(\mathrm{w} / \mathrm{r}$ and $\mathrm{wo} / \mathrm{r})$

\begin{tabular}{|c|c|c|c|c|c|c|}
\hline \multirow{2}{*}{ Phospahte Fertilizers } & & wo $/ \mathrm{r}$ & $\mathrm{w} / \mathrm{r}$ & \multirow{2}{*}{\multicolumn{3}{|c|}{$\begin{array}{l}\mathrm{wo} / \mathrm{r} \\
\mathrm{w}\end{array}$}} \\
\hline & \multicolumn{3}{|c|}{-------------------- Maize ------------------- } & & & \\
\hline & \multicolumn{6}{|c|}{----------------------------------- P content in flag leaf $\left(\mathrm{g} \mathrm{kg}^{-1}\right)$--------------------------- } \\
\hline Without $\mathrm{P}_{2} \mathrm{O}_{5}$ & $1.15^{*}$ & & & $1.30^{*}$ & & \\
\hline TSP & & $1.50 \mathrm{Ab}$ & $2.02 \mathrm{Aa}$ & & $1.51 \mathrm{Ab}$ & $2.05 \mathrm{Aa}$ \\
\hline APR & & $1.50 \mathrm{Ab}$ & $2.02 \mathrm{Aa}$ & & $1.51 \mathrm{Ab}$ & $1.93 \mathrm{Aa}$ \\
\hline \multirow[t]{2}{*}{$\mathrm{CV} \%$} & 10.1 & \multicolumn{5}{|c|}{14.8} \\
\hline & \multicolumn{6}{|c|}{--1-1-1- } \\
\hline Without $\mathrm{P}_{2} \mathrm{O}_{5}$ & $1.28^{*}$ & & & $1.75^{*}$ & & \\
\hline TSP & & $1.63 \mathrm{Ab}$ & $3.52 \mathrm{Aa}$ & & $2.32 \mathrm{Ab}$ & $3.47 \mathrm{Aa}$ \\
\hline APR & & $1.81 \mathrm{Ab}$ & 3.39Aa & & $1.95 \mathrm{Bb}$ & $2.96 \mathrm{Ba}$ \\
\hline $\mathrm{CV} \%$ & 25.8 & & & 16.3 & & \\
\hline
\end{tabular}

Note. * Control differs from remaining treatments. Means followed by distinct capital letters on the column and low capital letters on the row differ statistically by the $\mathrm{F}$ test $(<5 \%)$. Control: without $\mathrm{P}_{2} \mathrm{O}_{5}$ application, TSP: recommended dose of $\mathrm{P}_{2} \mathrm{O}_{5}$ as TSP with and without annual reapplication; APR: recommended dose of $\mathrm{P}_{2} \mathrm{O}_{5}$ as PR from Arad with and without annual reapplication with TSP.

Rice flag leaf P contents were kept below sufficient levels determined by the Committee of Soil Chemistry and Fertility-RS/SC (2004) for irrigated rice, which ranges from 2.4 to $4.8 \mathrm{~g} \mathrm{~kg}^{-1}$. However, the critical level of P in the flag leaf for modern rice cultivars according to Dobermann and Fairhurst (2000), and SOSBAI (2016) is 1.8 $\mathrm{g} \mathrm{kg}^{-1}$ and $1.7 \mathrm{~g} \mathrm{~kg}^{-1}$, respectively. If this criterion is used, the treatments with annual phosphate reapplication would be supplying the rice plants, while in other treatments (control and fertilizer applied only in the first year) plants would be P deficient. If one considers that the fertilizer amounts used in the treatments with fertilizer reapplication were sufficient to nourish the rice plants, the levels suggested by Dobermann and Fairhurst (2000), and SOSBAI (2016) seem to be more adequate than those suggested by the Committee of Soil Chemistry and Fertility-RS/SC (2004). 
Phosphate fertilization has also increased the $\mathrm{P}$ accumulated in the rice plants (Table 3 ) and the annual reapplication lead to higher accumulation levels, however it did not reflect on higher plant dry matter weight. Differences between phosphate sources were only obtained in the soybean desiccated residue area, where the TSP applied since the beginning of the experiment was higher than the APR with annual TSP reapplication.

Table 3. P accumulated and shoot (culms, leaves and grains) dry matter of rice plants from no-tillage areas after maize and soybean cultivation, with and without reapplication of phosphate fertilizer (w/r and wo/r)

\begin{tabular}{|c|c|c|c|c|c|c|}
\hline \multirow{2}{*}{ Phospahte Fertilizers } & & $\mathrm{wo} / \mathrm{r}$ & $\mathrm{w} / \mathrm{r}$ & \multirow{2}{*}{\multicolumn{3}{|c|}{$\begin{array}{ll}\mathrm{wo} / \mathrm{r} & \mathrm{w} / \mathrm{r} \\
\end{array}$}} \\
\hline & \multicolumn{3}{|c|}{------------------ Maize ----------------- } & & & \\
\hline & \multicolumn{6}{|c|}{ - Accumulated P $\left(\mathrm{g} \mathrm{m}^{-2}\right.$ ) - } \\
\hline Without $\mathrm{P}_{2} \mathrm{O}_{5}$ & $2.66^{*}$ & & & $4.04 *$ & & \\
\hline TSP & & $4.03 \mathrm{Ab}$ & 9.94Aa & & $6.06 \mathrm{Ab}$ & $8.92 \mathrm{Aa}$ \\
\hline APR & & $4.05 \mathrm{Ab}$ & 9.54Aa & & $3.91 \mathrm{Bb}$ & $6.24 \mathrm{Ba}$ \\
\hline \multirow[t]{2}{*}{$\mathrm{CV} \%$} & 35.5 & \multicolumn{5}{|c|}{25.3} \\
\hline & \multicolumn{6}{|c|}{ 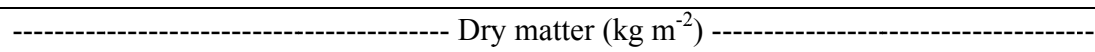 } \\
\hline Without $\mathrm{P}_{2} \mathrm{O}_{5}$ & $2.12^{\mathrm{ns}}$ & & & $2.39^{\text {ns }}$ & & \\
\hline TSP & & $2.47 \mathrm{Aa}$ & $2.95 \mathrm{Aa}$ & & $2.74 \mathrm{Aa}$ & $2.64 \mathrm{Aa}$ \\
\hline APR & & 2.39Aa & $2.88 \mathrm{Aa}$ & & $2.04 \mathrm{Ba}$ & $2.21 \mathrm{Ba}$ \\
\hline $\mathrm{CV} \%$ & 21.2 & & & 21.0 & & \\
\hline
\end{tabular}

Note. * Control differs from remaining treatments. Means followed by distinct capital letters on the column and low capital letters on the row differ statistically by the $\mathrm{F}$ test $(<5 \%)$. Control: without $\mathrm{P}_{2} \mathrm{O}_{5}$ application, TSP: recommended dose of $\mathrm{P}_{2} \mathrm{O}_{5}$ as TSP with and without annual reapplication; APR: recommended dose of $\mathrm{P}_{2} \mathrm{O}_{5}$ as PR from Arad with and without annual reapplication with TSP.

A correlation between $\mathrm{P}$ content on rice flag leaves and plant $\mathrm{P}$ accumulation is shown in Figure 2. Despite the correlation observed between these variables $(r=0.68)$, there was large point dispersal. For example, for an accumulated $P$ value of $5.0 \mathrm{~g} \mathrm{~m}^{-2}$, flag leaf $\mathrm{P}$ contents ranged from 1.25 to $2.25 \mathrm{~g} \mathrm{~kg}^{-1}$.

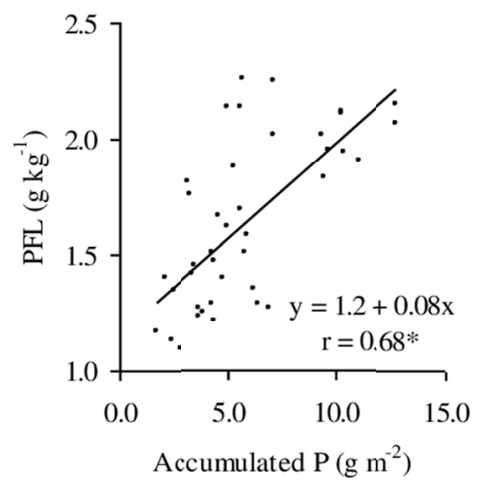

Figure 2. Correlation between rice flag leaf content (PFL) and accumulated phosphorus (accumulated P) from shoot (culms, leaves and grains) independently from the area. *Significant at $<1 \%$ probability

In Figures 3 and 4, the correlations between the $\mathrm{P}$ extracted by Mehlich-1 and AER at both depths and P accumulated in the rice shoot cultivated after maize (Figure 3) and after soybean (Figure 4) are shown. A correlation was observed for these two variables, with coefficient values ranging from 0.51 to 0.78 . 
a)

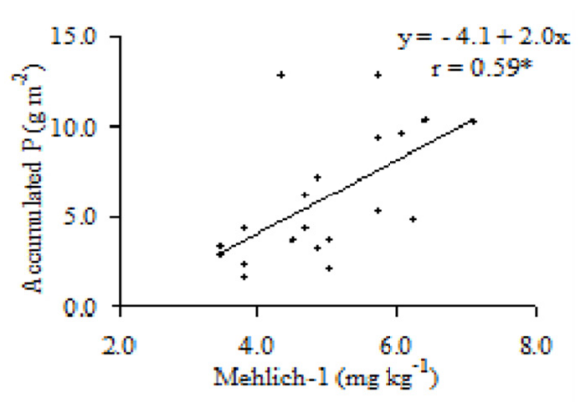

c)

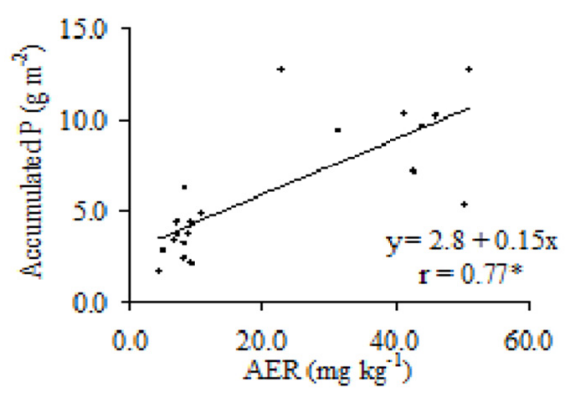

b)

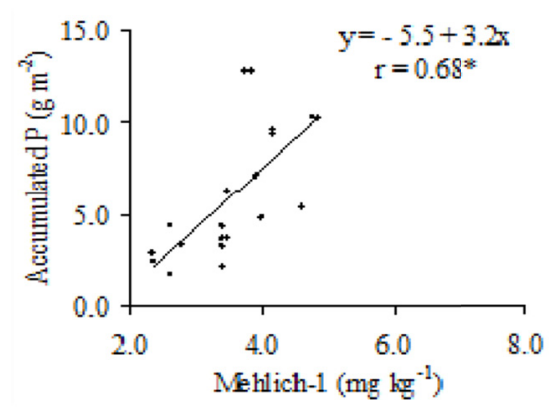

d)

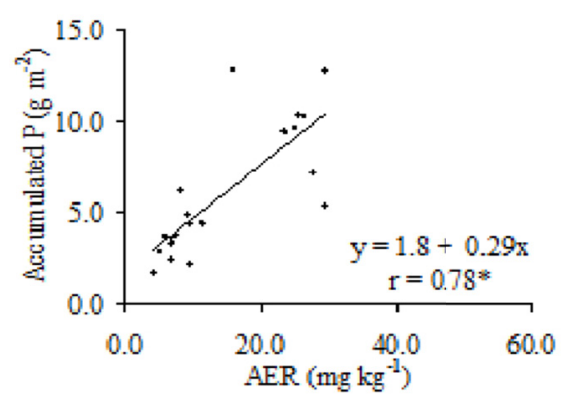

Figure 3. Correlations between shoot accumulated $\mathrm{P}$ and $\mathrm{P}$ extracted by different methods and soil depths after no-tillage cultivation with maize. (a) Mehlich-1 method from 0-10 cm; (b) Mehlich-1 method from 0-20 cm; (c) Anion Exchange resin (AER) from 0-10 cm; (d) Anion Exchange resin (AER) from 0-20 cm. *Significant $<1 \%$ probability

a)

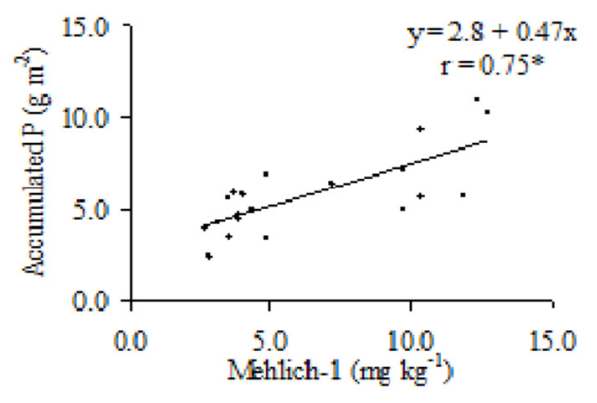

c)

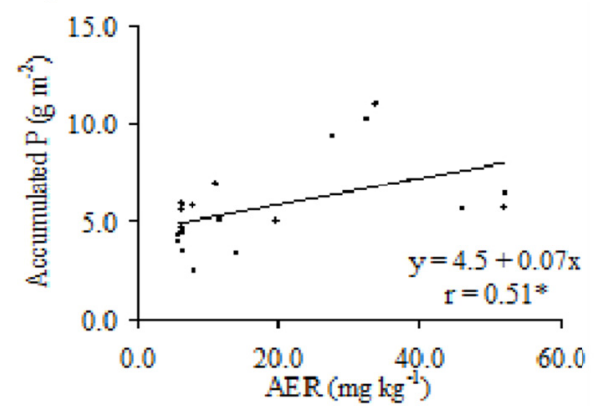

b)

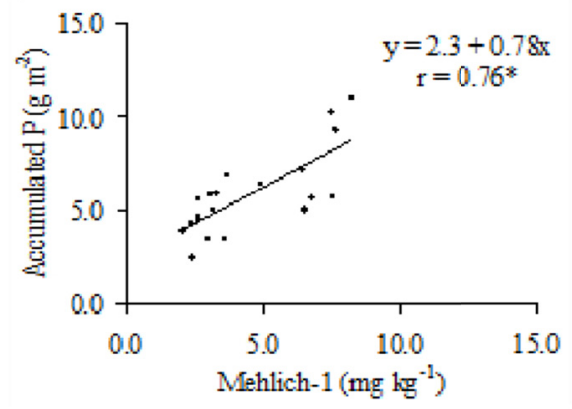

d)

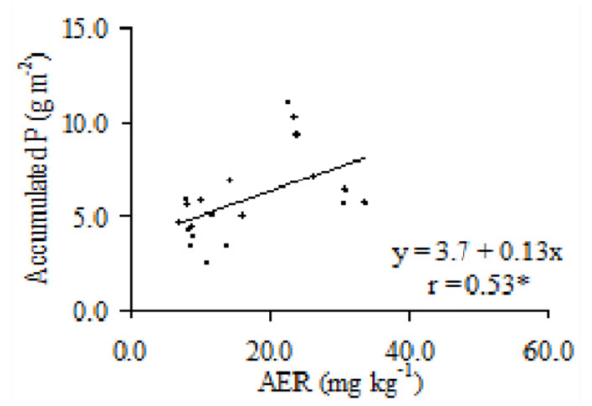

Figure 4. Correlations between shoot accumulated $\mathrm{P}$ and $\mathrm{P}$ extracted by different methods and soil depths after no-tillage cultivation with soybean. (a) Mehlich-1 method from 0-10 cm; (b) Mehlich-1 method from 0-20 cm; (c) Anion Exchange resin (AER) from 0-10 cm; (d) Anion Exchange resin (AER) from 0-20 cm. *Significant $<1 \%$ probability 
In the maize desiccated residue area (Figure 3), the shoot accumulated $\mathrm{P}$ was better correlated with $\mathrm{P}$ contents extracted with AER $(r=0.77$ and $r=0.78)$ than with Mehlich-1 $(r=0.59$ and $r=0.68)$ method. However, in the soybean stubble crop area (Figure 4), an opposite result was observed when compared to the maize area, where the rice plant $\mathrm{P}$ accumulation correlated better with $\mathrm{P}$ values obtained from the Mehlich-1 extractor $(\mathrm{r}=0.75$ and $r=0.76)$ rather than with AER $(r=0.51$ and $r=0.53)$. The higher correlation observed between $P$ accumulated and the $\mathrm{P}$ content obtained from AER in the maize area could have been caused by a concentration of data points in two regions of the graph, related to low and high $\mathrm{P}$ concentrations extracted by the resin. The occurrence of these two regions is related to treatments with and without annual $\mathrm{P}$ reapplication. Those are different from $\mathrm{P}$ values in Mehlich-1 extractions where there is a better distribution of data points along the straight line.

Other irrigated rice studies have shown that the $\mathrm{P}$ availability predictions by Mehlich-1 and AER are equivalent. Correlation coefficients between P values detected and plant P levels of 0.45 and 0.70 have been observed for Mehlich-1 and AER, respectively (Silva et al., 2008). On another report evaluating three lowland soils (Typic Albaqualf, Vertic Albaqualf and Typic Endoaqualf), where different TSP and Daoui phosphate rock doses were applied, correlation levels of 0.58 and 0.61 were observed for Mehlich-1 and AER, respectively (Cardoso, 2007). Higher values based on determination coefficients $\left(\mathrm{R}^{2}=0.88\right.$ for resin and $\mathrm{R}^{2}=0.83$ for Mehlich-1) were also observed (Gonçalves \& Meurer, 2008).

Even though the Mehlich-1 method is considered only fair for the prediction of P availability from Rio Grande do Sul State soils, no other method has shown a convincing superior performance in order to justify its replacement (Silva et al., 2008).

Grain yield (Table 4) was not affected by any of the applied treatments, suggesting that P amounts available in the soil were enough to achieve similar yields. Although $\mathrm{P}$ is usually a limiting factor for plants cultivated in highly drained soils, it seems not to be a limiting factor for irrigated rice, since its availability is higher under reducing conditions (Vahl \& Sousa, 2004). Increases in grain yields obtained from phosphate fertilizer experiments carried out on Albaqualf soil rarely reached over 20\% (Vahl, 2004).

Mathematical models have been widely used to perform growth, development and grain yield response studies under climate change scenarios, harvest prediction and also estimates of key developmental stages which are associated to management practices (Dingkuhn et al., 2015; Grassini et al., 2015). In Brazil, the most used SimulArroz, it simulates growth, development and grain yield in the rice crop, and was developed for cultivars used in the irrigated rice system (by flooding) in the State of Rio Grande do Sul (Rosa et al., 2015).

Table 4. Rice grain yield in no-tillage system after cultivation with maize or soybean, with and without reapplication of phosphate fertilizer $(\mathrm{w} / \mathrm{r}$ and wo/r)

\begin{tabular}{|c|c|c|c|c|c|c|}
\hline \multirow{2}{*}{ Phospahte Fertilizers } & & wo/r & $\mathrm{w} / \mathrm{r}$ & \multirow{2}{*}{\multicolumn{3}{|c|}{$\begin{array}{ll}\text { wo/r } & \text { w/r } \\
& \end{array}$}} \\
\hline & \multicolumn{3}{|c|}{-------------------- Maize ------------------ } & & & \\
\hline & \multicolumn{6}{|c|}{ - } \\
\hline Without $\mathrm{P}_{2} \mathrm{O}_{5}$ & $6.98^{\mathrm{ns}}$ & & & $8.06^{\mathrm{ns}}$ & & \\
\hline TSP & & $7.28^{\mathrm{ns}}$ & $7.77^{\mathrm{ns}}$ & & $8.80^{\mathrm{ns}}$ & $7.49^{\text {ns }}$ \\
\hline APR & & $7.14^{\mathrm{ns}}$ & $7.92^{\mathrm{ns}}$ & & $8.07^{\text {ns }}$ & $8.24^{\mathrm{ns}}$ \\
\hline $\mathrm{CV} \%$ & 10.3 & & & 10.7 & & \\
\hline
\end{tabular}

Note. ${ }^{\text {ns }}$ No differences detected between treatments. Control: without $\mathrm{P}_{2} \mathrm{O}_{5}$ application; TSP: recommended dose of $\mathrm{P}_{2} \mathrm{O}_{5}$ as TSP with and without annual reapplication; APR: recommended dose of $\mathrm{P}_{2} \mathrm{O}_{5}$ as PR from Arad with and without annual reapplication with TSP.

Upland crops cultivated before rice did respond to the phosphate fertilizer, regardless of the source used. For maize and soybean, the grain yields were $100 \%$ and $50 \%$ higher than the control (no fertilizer), respectively (data not shown). These results indicate that upland crops respond better to phosphate fertilizer than irrigated rice.

According to Lang et al. (2016), the gradual corrective phosphate fertilization in the row resulted in higher yield and grain quality of upland rice when compared to its absence. Also, in the upland rice crop, the use of triple superphosphate promoted increases in the number of tillers and panicles.

The lack of response of rice to the fertilizer harms the comparison of phosphate sources used. However, in general $\mathrm{P}$ contents in the soil and in the plants were equivalent between sources. Therefore, it is possible to infer that the use of phosphate rocks on upland crops preceding rice can be a viable alternative. Other studies have 
shown that reactive phosphate rocks can be efficient in rotating systems using irrigated rice and upland crops (Gomes et al., 2005; Ferreira et al., 2007).

The $\mathrm{P}$ content in the flag leaves and the $\mathrm{P}$ accumulated in the rice shoot did not correlate with grain yield (Figure 5). Thus, a better plant nutrition regarding $P$ did not lead to an increase in grain yield, which is an indication that rice plants are well nourished by the element, even in the plots that did not receive P. The critical levels of deficiency pointed either by the Committee of Soil Chemistry and Fertility-RS/SC (2004) and by Dobermann and Fairhurst (2000) as already discussed, probably are not indicated when evaluating an adequate level of P nutrition observed in the experiments.

a)

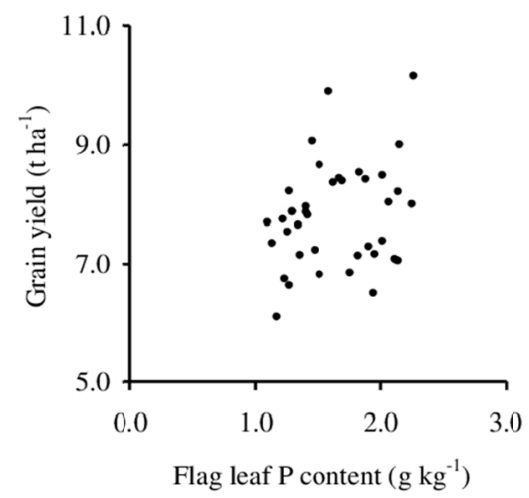

b)

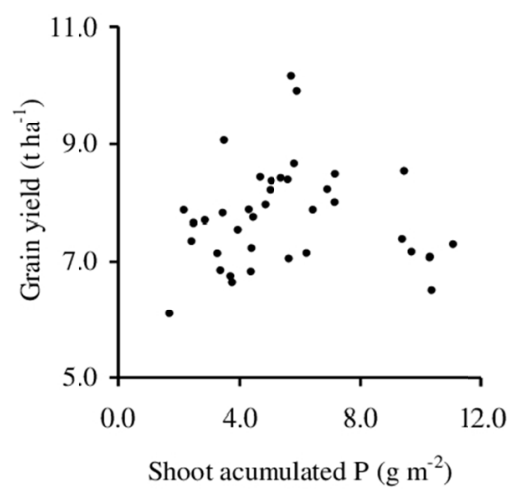

Figure 5. Correlation of $\mathrm{P}$ contents and grain yield as a function of phosphate fertilizer. (a) between flag leaf $\mathrm{P}$ content and grain yield; (b) between shoot accumulated $\mathrm{P}$ and grain yield

Such indices have also been questioned by Pocojeski (2007), which did not observe yield decreases in plants with $\mathrm{P}$ contents below the levels established as deficient by those authors. It is possible that these discrepancies are related to the fact that the levels established by those authors have not been tested in soil and climate conditions of Rio Grande do Sul and/or with rice cultivars used in the State.

\section{Conclusions}

Rice grain yields did not respond to the phosphate fertilizer, even with soil initial $\mathrm{P}$ contents below the critical level of deficiency $\left(<6.0 \mathrm{mg} \mathrm{dm}^{-3}\right)$.

The phosphate fertilization performed on the upland crops (maize and soybean) presented a residual effect for the irrigated rice even after four years of cultivation, in the no-tillage system.

The Mehlich-1 and anion exchange resin extractors were equally efficient in the evaluation of $\mathrm{P}$ availability for the irrigated rice. The soil $\mathrm{P}$ values obtained through both methods did show significant correlations with $\mathrm{P}$ accumulated in the plants.

The Arad phosphate rock presents a similar performance as triple superphosphate regarding the $\mathrm{P}$ nutrition in irrigated rice cultivated in rotation with upland crops under no-tillage.

\section{Acknowledgements}

The FAPERGS, CNPq and CAPES for granting study and financial assistance grants for the realization of this work.

\section{References}

Amer, F., Boudin, D. R., Black, C. A., \& Duke, F. R. (1955). Characterization of soil phosphorus by anion exchange resin adsorption and $\mathrm{P}^{32}$-equilibration. Plant and Soil, 6(4), 391-408. https://doi.org/10.1007/ BF01343648

Anghinoni, I. (2006). Adubação fosfatada e potássica em plantio direto. In S. M. V. Fontoura, \& C. Bayer (Eds.), Manejo e fertilidade de solos em plantio direto (pp. 87-104). Guarapuava, PR: Fundação Agrária de Pesquisa Agropecuária. 
Bortolon, L. (2005). Métodos de avaliação da disponibilidade de nutrientes para as plantas em solos do Rio Grande do Sul (Master's thesis, Universidade Federal do Rio Grande do Sul, Porto Alegre, Brazil). Retrieved from http://www.lume.ufrgs.br/handle/10183/13766

Cardoso, E. F. (2007). Adubação fosfatada para o arroz irrigado em solos com diferentes capacidades de adsorção de fósforo (Master's thesis, Universidade Federal de Pelotas, Pelotas, Brazil). Retrieved from http://repositorio.ufpel.edu.br/handle/123456789/1162

Chang, S. C., \& Jackson, M. L. (1957). Fractionation of soil phosphorus. Soil Science, 84(2), 133-144. https://doi.org/10.1097/00010694-195708000-00005

Committee of Soil Chemistry and Fertility-RS/SC. (2004). Manual de adubação e de calagem para os Estados do Rio Grande do Sul e de Santa Catarina (10th ed.). Porto Alegre: Sociedade Brasileira de Ciência do Solo, Núcleo Regional Sul. Retrieved from http://www.sbcs-nrs.org.br/docs/manual_de_adubacao_2004_versao_ internet.pdf

Committee of Soil Chemistry and Fertility-RS/SC. (2016). Manual de calagem e adubação para os Estados do Rio Grande do Sul e de Santa Catarina (11th ed.). Porto Alegre: Sociedade Brasileira de Ciência do Solo, Núcleo Regional Sul.

Dingkuhn, M., Laza, M. R. C., Kumar, U., Mendez, K. S., Collard, B., Jagadish, K., ... Sow, A. (2015). Improving yield potential of tropical rice: Achieved levels and perspectives through improved ideotypes. Field Crops Research, 182, 43-59. https://doi.org/10.1016/j.fcr.2015.05.025

Dobermann, A., \& Fairhurst, T. (2000). Rice: Nutrient Disorders and Nutrient Management. Manila, PH: International Rice Research Institute (IRRI), Potash e Phosphate Institute (PPI), Potash \& Phosphate Institute of Canada (PPIC). Retrieved from http://www.ipni.net/ppiweb/filelib.nsf//2BB52995AF6F76E24 8257074002997BC/\$file/TOC\%20Rice\%20HB.pdf

Ferreira, L. H. G., Gomes, A. S., Scivittaro, W. B., Pereira, R. S. D., Winkler, A. S., \& Chiarelo, C. (2007). Efeito imediato e residual da adubação fosfatada na cultura do arroz irrigado por inundação sobre a produtividade de grãos de arroz (pp. 528-531). V Congresso Brasileiro de Arroz Irrigado, Pelotas, Brasil.

Freitas, I. F., Novais, R. F., Villani, E. M. A., \& Novais, S. V. (2013). Phosphorus extracted by ion exchange resins and mehlich-1 from oxisols (latosols) treated with different phosphorus rates and sources for varied soil-source contact periods. Revista Brasileira de Ciência do Solo, 37(3), 667-677. https://doi.org/ $10.1590 / \mathrm{S} 0100-06832013000300013$

Gatiboni, L. C. (2003). Disponibilidade de formas de fósforo do solo às plantas (Master's thesis, Universidade Federal de Santa Maria, Santa Maria, Brasil). Retrieved from http://repositorio.ufsm.br/handle/1/3154

Gomes, A. S., Ferreira, L. H. G., \& Bender, R. R. (2005). Uso de fosfato natural no cultivo de arroz, soja e milho em rotação, no sistema plantio direto. Pelotas, RS: Embrapa Clima Temperado. Retrieved from https://ainfo.cnptia.embrapa.br/digital/bitstream/item/43871/1/boletim-20.pdf

Gonçalves, G. K., \& Meurer, E. J. (2008). Disponibilidade de Fósforo em Solos Cultivados com Arroz Irrigado por Alagamento no Rio Grande do Sul. Revista Brasileira de Ciência do Solo, 32, 2745-2750. https://doi.org/10.1590/S0100-06832008000700018

Grassini, P., Torrion, J. A., Yang, H. S., Rees, J., Andersen, D., Cassman, K. G., \& Specht, J. E. (2015). Soybean yield gaps and water productivity in the western U.S. Corn Belt. Field Crops Research, 179, 150-163. https://doi.org/10.1016/j.fcr.2015.04.015

Kurihara, C. H., Silva, W. R., Dias, M. M., Tsujigushi, B. P., \& Silva, J. V. S. (2016). Gradual correction of phosphorus availability in the no-tillage system. Revista Ceres, 63(2), 256-264. https://doi.org/10.1590/ 0034-737X201663020018

Lindsay, W. L. (1979). Chemical equilibrium in soils. New York, NY: John Wiley \& Sons. Retrieved from http://soils.ifas.ufl.edu/lqma/SEED/CWR6252/Handout/Chemical\%20equilibira.pdf

Machado, A. (2001). Winstat—Sistema de análises estatísticas para o Windows [Versão 1.0, CD-ROM]. Pelotas, RS: Núcleo de Informática Aplicada (NIA), Universidade Federal de Pelotas.

Nakamura, S., Fukuda, M., Issaka, R. N., Dzomeku, I. K., Buri, M. M., Avornyo, V. K., ... Tobita S. (2017). Residual effects of direct application of Burkina Faso phosphate rock on rice cultivation in Ghana. Nutrient Cycling Agroecosystems, 106, 47-59. https://doi.org/10.1007/s10705-016-9788-8 
Oliveira, C. M. B., Gatiboni, L. C., Ernani, P. R., Boitt, G., \& Brunetto, G. (2015). Capacidade de predição da disponibilidade de fósforo em solo com aplicação de fosfato solúvel e natural. Científica, 43(4), 413-419. https://doi.org/10.15361/1984-5529.2015v43n4p413-419

Pocojeski, E. (2007). Estimativa do estado nutricional de arroz irrigado por alagamento (Master's thesis, Universidade Federal de Santa Maria, Santa Maria, Brasil). Retrieved from https://repositorio.ufsm.br/ handle/1/5584

Ponnamperuma, F. N. (1972). The chemistry of submerged soils. Advances in Agronomy, 24, $29-96$. https://doi.org/10.1016/S0065-2113(08)60633-1

Raij, B. van, Quaggio, J. A., \& Silva, M. N. (1986). Extraction of phosphorus, potassium, calcium and magnesium from soil by anion-exchange resin procedure. Science of Plant Analysis, 17(5), 547-566. https://doi.org/10.1080/00103628609367733

Rogeri, D. A., Bortolon, L., Gianello, C., \& Amorim, M. B. (2017). Remaining phosphorus content to determine phosphorus availability of the soils in Rio Grande do Sul. Pesquisa Agropecuária Brasileira, 52(12), 1203-1214. https://doi.org/10.1590/s0100-204x2017001200009

Rosa, H. T., Walter, L. C., Streck, N. A., Carli, C. de, Ribas, G. G., \& Marchesan, E. (2015). Simulação do crescimento e produtividade de arroz no Rio Grande do Sul pelo modelo SimulArroz. Revista Brasileira de Engenharia Agrícola e Ambiental, 19, 1159-1165. https://oi.org/10.1590/1807-1929/agriambi.v19n12 p1159-1165

Silva, F. C., \& Raij, B. V. (1996). Avaliação da disponibilidade de fósforo por diversos extratores em amostras de solo cultivados com cana-de-açúcar. Revista Brasileira de Ciência do Solo, 20(1), 83-90.

Silva, L. S., Ranno, S. K., Rhoden, C., Santos, D. R., \& Graupe, A. (2008). Avaliação de métodos para estimativa da disponibilidade de fósforo para arroz em solos de várzea do Rio Grande do Sul. Revista Brasileira de Ciência do Solo, 32(1), 207-216. https://doi.org/10.1590/S0100-06832008000100020

Simonete, M. A., Ernani, P. R., Moro, L., Teixeira-Gandra, C. F. A., \& Gatiboni, L. C. (2015). Eficiência de métodos analíticos na predição da disponibilidade de fósforo Para arroz irrigado em solos catarinenses. Revista Brasileira de Ciência do Solo, 39(4), 1151-1160. https://doi.org/10.1590/01000683rbcs20140797

Skogey, O., \& Dobermann, A. (1996). Synthetic ion-exchange resins: Soil and environmental studies. Journal Environmental Quality, 25, 13-24. https://doi.org/10.2134/jeq1996.00472425002500010004x

Soil Survey Staff. (2010). Keys to soil taxonomy (11th ed.). United States Department of Agriculture, Natural Resources Conservation Service, Washington, DC. Retrieved from https:/www.nrcs.usda.gov/Internet/ FSE_DOCUMENTS/nrcs142p2_050915.pdf

SOSBAI. (Sociedade Sul-Brasileira de Arroz Irrigado). (2007). Arroz irrigado: Recomendações técnicas da pesquisa para o Sul do Brasil. XXX Reunião Técnica da Cultura do Arroz Irrigado, Bento Gonçalves, RS, Brazil. Retrieved from https://www.agencia.cnptia.embrapa.br/Repositorio/Recomendacoes_Tecnicas_Arr oz_2007_000fzrbdd8b02wx5ok0cpoo6adaexge2.pdf

SOSBAI. (Sociedade Sul-Brasileira de Arroz Irrigado). (2016). Arroz irrigado: Recomendações técnicas da pesquisa para o Sul do Brasil. XXXI Reunião Técnica da Cultura do Arroz Irrigado, Bento Gonçalves, RS, Brazil. Retrieved from http://www.sosbai.com.br/docs/Boletim_RT_2016.pdf

Steiner, F., Lana, M. C., Zoz, T., Frandoloso, J. F., \& Fey, R. (2012). Extraction methods and availability of phosphorus for soybean in soils from Paraná State, Brazil. Semina: Ciências Agrárias, 33, 1005-1014. https://doi.org/10.5433/1679-0359.2012v33n3p1005

Tedesco, M. J., Gianello, C., Bissani, C. A., Bohnen, H., \& Volk Weiss, S. J. (1995). Análise de solo, plantas e outros materiais (2nd ed., Boletim Técnico, No. 5). Porto Alegre: Departamento de Solos, UFRGS.

Vahl, L. C. (2004). O Fósforo na Cultura do Arroz Irrigado. In T. Yamada, \& S. R. S. Abdalla (Eds.), Fósforo na Agricultura Brasileira (pp. 419-434). Associação Brasileira para Pesquisa da Potassa e do Fosfato, Piracicaba, SP.

Vahl, L. C., \& Sousa, R. O. (2004). Aspectos físico-químico de solos alagados. In A. S. Gomes, \& A. M. de Magalhães Jr. (Eds.), Arroz irrigado no Sul do Brasil. Pelotas: Embrapa Clima Temperado; Brasília: Embrapa Informação Tecnológica (pp. 97-118). Brasil: Brasília, DF.

Zimmermann, F. J. P. (2004). Estatística aplicada à pesquisa agrícola. Embrapa Arroz e Feijão. Santo Antônio de Goiás, GO. Retrieved from http://livimagens.sct.embrapa.br/amostras/00075760.pdf 


\section{Copyrights}

Copyright for this article is retained by the author(s), with first publication rights granted to the journal.

This is an open-access article distributed under the terms and conditions of the Creative Commons Attribution license (http://creativecommons.org/licenses/by/4.0/). 